\title{
Climate-Related Hazards and Internal Migration Empirical Evidence for Rural Vietnam
}

\author{
Michael Berlemann ${ }^{1} \cdot$ Thi Xuyen Tran ${ }^{1}$
}

Received: 21 December 2019 / Accepted: 16 March 2020 / Published online: 21 April 2020

(C) The Author(s) 2020

\begin{abstract}
In this paper we employ commune-level data from Vietnam to study whether three types of natural disasters have an impact on emigration figures. We thereby distinguish between temporary and permanent emigration and also differentiate between the effects of recently occurring disaster events and changes in medium-term disaster trends. We find that episodic droughts and flood events tend to cause emigration from the affected communes. While droughts primarily cause temporary migration, flood events tend to induce permanent moves out of the affected regions. Whenever drought or flood events are perceived to have become more severe over the last decade, we also find systematically higher emigration from the affected communes. Episodic typhoons or worsening typhoon trends remain without any significant effect in both the short- and the long-run.
\end{abstract}

Keywords Climate change $\cdot$ Natural hazards $\cdot$ Migration $\cdot$ Vietnam

\section{Introduction}

Global warming, i.e. the upward trend of the average surface temperature since the early 20th century, and most notably since the late 1970s, already has and will continue to change the living conditions on planet Earth. While the average annual surface temperature fluctuates only slightly around an upward trend, there is a much stronger effect on temperature variability and temperature extremes (Rummukainen 2012). Moreover, an increase in the mean temperature has a direct impact on atmospheric moisture and results in an increase of global precipitation and more severe precipitation extremes (Kharin et al. 2007; Westra

Michael Berlemann

Michael.Berlemann@hsu-hh.de

Thi Xuyen Tran

tranx@hsu-hh.de

1 Helmut-Schmidt-University, Holstenhofweg 85, 22043 Hamburg, Germany 
et al. 2014). ${ }^{1}$ Global warming will most likely also increase the number and/or the severity of other climate-related hazards such as droughts (Dai 2011), wildfires (Liu et al. 2009) and floods (Hirabayashi et al. 2013). While the literature has yet not reached a consensus on whether global warming contributes to a change in tropical storm frequency (Knutson et al. 2010; Thomas 2014), storm severity is expected to further increase (Bender et al. 2010; Christensen et al. 2007).

Migration is possibly the most direct but also the most extreme adaptation strategy to global warming (Reid 2014). The Intergovernmental Panel on Climate Change (IPCC) expected already in 1990 that human migration will be the greatest single impact of climate change with millions of people displaced (Ionesco et al. 2017). Since the early 2000s the literature on the effects of climate and climate-related hazards developed rapidly but failed to deliver a clear picture (Berlemann and Steinhardt 2017). Various studies found little or no empirical evidence for international climate or disaster migration (e.g. Beine and Parsons (2015), Ruyssen and Rayp (2014), and Gröschl and Steinwachs (2017)) whereas others come to the opposite result (e.g. Beine and Parsons (2017), Coniglio and Pesce (2015), Backhaus et al. (2015), and Cattaneo and Peri (2016). Similarly, the evidence for internal migration in consequence of climate change and climate-induced hazards is mixed. Whereas parts of the literature find supporting evidence for internal migration (e.g. Dallmann and Millock (2017), Gröger and Zylberberg (2016), Henry et al. (2004), Bohra Mishra et al. (2014), and Thiede et al. (2016), others do not (e.g. Di Falco et al. (2012), Gray and Bilsborrow (2013), and Goldbach (2017)).

To a significant extent, the mixed results are due to methodological differences between the existing studies (Berlemann and Steinhardt 2017). However, there is also evidence that the effects might depend on the institutional setting in the affected countries, which are often hard to measure. Thus, single country studies are urgently necessary to complete the picture on the effects of climate-induced natural hazards.

In this paper we focus on Vietnam, a Southeast-Asian country which is strongly affected by climate change and prone to various sorts of climate-induced natural disasters. While the existing evidence on Vietnam either concentrates on single disaster events (Gröger and Zylberberg 2016) or distinguishes between groups of disasters (sudden onset versus slow-onset, see Koubi et al. (2016a, b)), we study the effect of three major types of natural disasters (droughts, floods and typhoons) separately within a panel estimation approach. In order to do so we employ three waves of the Vietnam Access to Resources Household Survey (VARHS). The commune-level version of this survey contains information on emigration figures as well as on the occurrence of natural disasters, which to the best of our knowledge has not been used to study migration issues before. We study the short-run (1-2 years) as well as the long-run perspective (10 years) and, moreover, distinguish between temporary and permanent migration.

In the short-run, only drought events tend to cause emigration from the affected communes. While droughts primarily cause temporary migration, flood events, if at all, tend to induce permanent moves out of the affected regions. We find no short-run migration effects for typhoons. Whenever drought or flood events are perceived to have become more severe over the last decade, we find systematically higher emigration figures. Again, typhoon trends remain without any significant effect.

\footnotetext{
${ }^{1}$ Lehmann et al. (2015) show that between 1980 and 2010 the number of record-breaking precipitation events per year has significantly increased on the global level.
} 
The paper is organized as follows. The second section provides a brief review of the existing literature on disaster-induced migration in Vietnam. The third section delivers important information on Vietnam's geography, economy, climate and population. Section four introduces the employed data and delivers summary statistics. In section five we explain our estimation strategy and discuss the estimation results. Section six summarizes and concludes.

\section{Related Literature}

The literature on climate, natural hazards and migration has evolved quickly over the last decade. We make no attempt at summarizing this literature here in detail as actual survey articles are readily available (see e.g. Millock (2015) or Berlemann and Steinhardt (2017)). Instead we focus on discussing those papers which have been concerned with the influence of climate and natural disasters on internal migration in Vietnam. To the best of our knowledge, only four papers have yet studied these issues.

The first paper by Dun (2011) has a more explorative rather than econometric character. The research question the author aims to answer is whether the quite regularly occurring flood events in the Mekong Delta induce households to move out of the flood-prone areas. The analysis is based on a survey among 32 Vietnamese migrants in Cambodia, 12 semi-structured interviews with internal migrants who moved out of the Mekong Delta and 12 interviews with resettled people. Moreover, the author conducted 45 interviews with experts from governmental institutions, international organizations, academics and non-governmental organizations. The surveys and interviews were conducted in between October and December 2007. The authors find evidence for seasonal labor migration throughout the flood season, which is often associated with moving to urban areas. In addition to that, the results imply that at least successive floodings might lead to permanent emigration. Besides, there are indications that in the aftermath of flood events human trafficking increases and children are sent to larger cities.

The studies by Koubi et al. (2016a, b) are concerned with the effect of natural disasters on internal migration. They are both based on a survey of individuals aged 18 to 64 . The survey was conducted in 2013 with 1,200 respondents from 4 Vietnamese provinces. The interviewees answered whether they had experienced sudden-onset events (heavy rain, flood, hail, storm, cyclone, typhoon and/or landslide/ mudslide) and/or slow-onset events (salinity, drought, or desertification) during the past 5 years. The authors argue that migration as adaption strategy is more likely to be chosen in the case of sudden-onset events (in comparison to slow-onset events) as individuals have less possibilities to adjust to these incidents. To test this hypothesis, the survey regions were chosen on the basis of the type of hazards, the province is primarily concerned with (based on the EM-DAT database). ${ }^{2}$ While two provinces (Ben Tre, Ninh Thuan) are mainly affected by slow-onset events such as progressive salinity of its main waterway (the Mekong river) or droughts, the other two provinces (An Giang, Nam Dinh) are mainly subject to short-term environmental events such as floods and cyclones. Using a logit estimation approach the authors in fact find systematically positive migration effects of sudden (disaster) events whereas gradual (climatic) events reduce significantly migration.

\footnotetext{
${ }^{2}$ See http://www.emdat.be/
} 
Gröger and Zylberberg (2016) analyze the consequences of typhoon Ketsana which occurred in 2009 in parts of Vietnam. The empirical analysis is based on three subsequent surveys in 2007, 2008 and 2010, conducted for 2,200 households in 110 Vietnamese communes. Employing a difference-in-differences approach, the authors first show that households in affected communes suffer from a large negative income shock, as agricultural production is negatively affected. The authors also find a negative effect on consumption, however, this effect turns out to be much smaller than the underlying income effects. The reason why households did not have to restrict their consumption by the same amount as the income shock is that the affected households receive more remittances from labor migrants in non-affected communes (not from individuals from the same commune). Moreover, Gröger and Zylberberg (2016) provide evidence that non-migrant households tend to send household members to different communes in the aftermath of the typhoon, which increased their level of received remittances. Altogether, the study by Gröger and Zylberberg (2016) strengthens the argument for migration as an instrument to insure against consumption/income risk, put forward in earlier work by Rosenzweig and Stark (1989). As Gröger and Zylberberg (2016) (have to) concentrate their in-depth analysis on a single typhoon event it remains open for future research whether their central finding can be generalized.

\section{Climate, Natural Hazards and Migration Patterns in Vietnam}

Before we turn to the empirical analysis we should give a brief overview on Vietnam's geography, climate and the typical migration patterns. Vietnam is located in the eastern part of the Indochinese peninsula. It occupies roughly 331,230.8 square kilometers and has a population of roughly 94.67 millions (2018). Until the mid of the 1980s Vietnam was among the poorest countries of the world. Since 1986, the "Doi Moi" policy made Vietnam a market economy with a socialist orientation. The economic and political reforms under Doi Moi have spurred rapid economic growth and development and transformed Vietnam to a lower middle-income country (Revilla Diez 2016).

\section{Climate}

The World Bank (2010) has ranked Vietnam among the countries likely to be most affected by climate change since Vietnam has a long coastline of roughly 3200 kilometers and is located in the South East Asian tropical monsoon area. The climate in Vietnam differs greatly between north and south because of the effect of the monsoons. The north-east monsoon and the south-east monsoon affect Vietnam's north, making it cold in a long winter period. The south of Vietnam is less impacted by the north-east winter monsoon and, therefore, this region has a tropical climate that is hot over almost the full year (Huynh et al. 2014). Both types of monsoons differ considerably in their strength from year to year.

Because of the monsoons, the annual mean temperature in Vietnam is relatively lower than in many other countries in Asia at the same latitude (Huynh et al. 2014). The temperature in Vietnam increases gradually from the North to the South and fluctuates significantly between seasons (Katzfey et al. 2014). According to the Ministry of Natural Resources and Environment of Vietnam (2016), the average temperature in Vietnam has increased by roughly $0.1^{\circ} \mathrm{C}$ per decade over the period of 1958 to 2014. It has also been observed that extreme temperature events happen more frequently (Ministry of Natural Resources and Environment of Vietnam 2016). According to projections (Ministry of Natural Resources 
and Environment of Vietnam 2016) the annual average temperature is expected to further increase.

Vietnam is a comparatively humid country. The annual fluctuations of relative humidity are heavily influenced by precipitation. In general, the annual rainfall in the north exceeds that in the south. Precipitation during the rainy season accounts for more than 80 percent of annual precipitation (Nguyen et al. 2014). The number of rainy days varies strongly between the regions. Over the last 50 years, the northern regions of Vietnam witnessed a considerable decrease in precipitation in the rainy season while the southern regions experienced a significant increase in rainfall (Ministry of Natural Resources and Environment of Vietnam 2016; Schmidt - Thome et al. 2015). However, during the dry season, precipitation increased slightly or remained almost unchanged in the north, but increased dramatically in the south.

\section{Natural Hazards}

Vietnam is among the most disaster prone regions in the world (Global Facility for Disaster Reduction and Recovery 2011). Many of the occurring disasters are linked to climate. The earlier summarized climate trends indicate that climate-induced natural disasters will become either more frequent or severe.

Vietnam is strongly affected by flood events. Over the last two decades, Vietnam suffered from more than 70 floods that killed 5,024 people and destroyed 220,000 houses (Trung 2015). Floods occur mainly in the Red River Delta, the Central and the Mekong River Delta (Pilarczyk and Nuoi 2005). In the Red River Delta, the combination of intense rainfall and tidal effects is the main reason for floods. In the central region, floods are caused by a mixture of intense precipitation, short and steep watersheds and shortage of water storage capacities. In contrast, the major reason for flood events in the Mekong River Delta is the topography, which makes drainage difficult (Dun 2011). This creates prolonged floods as well as salinity intrusion. According to Trung (2015) the number of floods per year increased significantly throughout the period from 1990 to 2009.

A second severe threat to the Vietnamese population are typhoons. On average, Vietnam experiences 7 tropical depressions and typhoons per year. The majority of these hazards originate from the East Sea and the Western Pacific Ocean where storms happen most frequently in the world. Typhoons in Vietnam take place mostly in between June and December. Particularly provinces in the central region are affected heavily (Institute of Strategy and Policy on Natural Resources and Environment of Vietnam 2009). As reported by the Global Facility for Disaster, Reduction and Recovery 2011, typhoons have caused enormous damage in Vietnam. ${ }^{3}$ Throughout the period of 1959 to 2015 the number of heavy typhoons increased slightly. The typhoon season tends to last longer and typhoons tend to move southward as well (Ministry of Natural Resources and Environment of Vietnam 2016).

Finally, Vietnam is also prone to drought events. Naturally, droughts typically occur in the dry season, i.e. in between November and March (Vu - Thanh et al. 2013). As wellfunctioning irrigation systems are often unavailable, drought is a severe threat to agricultural business. Over the period of 1961 to 2007 the number of droughts increased significantly in the northern regions of Vietnam, whereas no significant trend could be observed for the south ( Vu - Thanh et al. 2013). According to predictions, droughts in Vietnam are likely to become more serious because climate change contributes to increasing rainfall variation

\footnotetext{
${ }^{3}$ Estimates amount to 4.5 billion USD over the past century.
} 
between seasons and more heatwaves (Global Facility for Disaster Reduction and Recovery 2011).

\section{Internal Migration in Vietnam}

Almost 14 percent of the Vietnamese population do not live their place of origin (General Statistics Office of Vietnam and United Nations Population Fund 2016). In Vietnam most individuals move from rural to urban areas. The two largest cities Ha Noi and Ho Chi Minh City are the most attractive destinations and receive the most migrants (General Statistics Office of Vietnam and United Nations Population Fund 2016).

In Vietnam, residents are classified as either permanent or temporary. The residence status is specified in a household registration booklet that contains all information about names, birthday, birthplace, address, gender, religion, occupation and identity number of the household's head and household's members. Moreover, this booklet registers the place of permanent residence. In order to be allowed to purchase or sell land, to make use of public education and health institutions, to apply for bank loans or to be hired as public servant an individual must be registered as permanent resident of the related commune (Duong et al. 2011). Whenever individuals are living apart from their permanent residence, they are registered as temporary residents and have much less access to public services. Thus, whenever individuals move permanently to a different commune they have a strong incentive to register as permanent resident, there. Nevertheless, a significant share of people moving for longer periods of time to different places keep their permanent residence status at their place of origin.

\section{Data}

For our empirical analysis we make use of the Vietnam Access to Resources Household Survey (VARHS). The VARHS was first implemented in 2002 to deliver information for the Doi Moi policy, in which rural households play an important role. It was noticed at that time, that little systematic information was available on the characteristics of the existing rural markets for land, credit and labor and the access of rural households to these markets. Since 2006, the VARHS has been conducted regularly every two years by the Development Economics Research Group (DERG) of the University of Copenhagen in collaboration with the Central Institute for Economic Management (CIEM), the Institute for Labor Studies and Social Affairs (ILSSA) and the Institute of Policy and Strategy for Agriculture and Rural Development Vietnam (IPSARD). Within the VARHS, data on both the household and the commune level are collected.

The survey covers around 470 communes in twelve provinces, located all over Vietnam. ${ }^{4}$ When the regular survey was started in 2006, households were chosen to constitute a representative sample of the rural areas in the twelve provinces in that year. ${ }^{5}$ For the later waves of the survey the sample is not provincially representative in a strict statistical sense because the primary aim was to construct a panel dataset (Brandt and Tarp 2017). Figure 1 shows which communes are included in the VARHS sample.

\footnotetext{
${ }^{4}$ The included provinces are: Ha Noi, Lao Cai, Phu Tho, Lai Chau, Dien Bien, Nghe An, Quang Nam, Khanh Hoa, Dak Lak, Dak Nong, Lam Dong, and Long An.

${ }^{5}$ See Brandt and Tarp (2017) for more detailed information on the survey and the sampling procedure.
} 


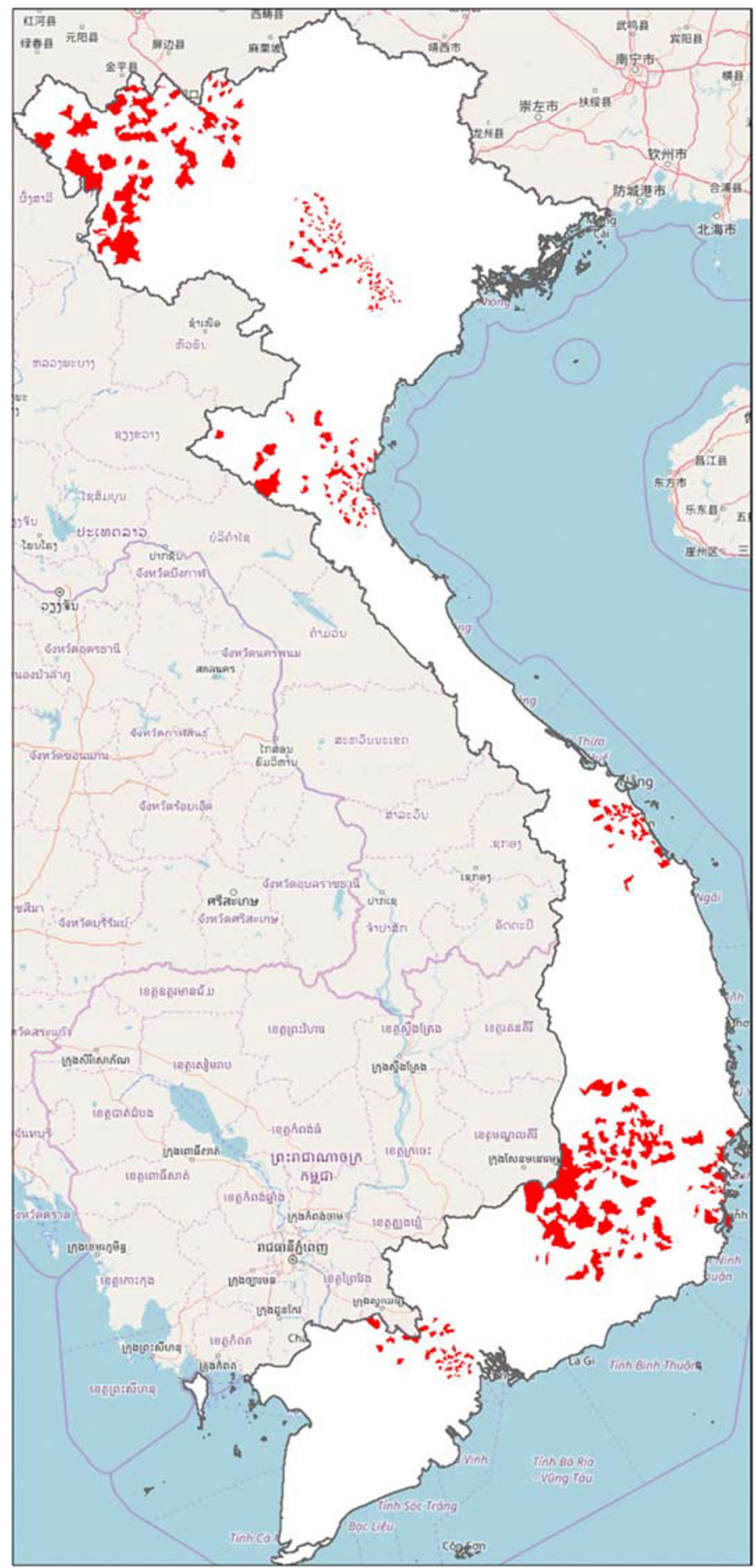

Fig. 1 Sample of Vietnamese Communes in the VARHS survey 
In this paper we employ solely the VARHS commune data. The commune questionnaires are answered by commune administrative officials, working in the relevant divisions. The respondents answer the questions based on their official records, when available.

Data on migration figures is available in the VARHS not before 2012. As this data is constitutive for our empirical analysis, we base our analysis on the three waves of the survey which were available when this paper was written, i.e. 2012, 2014 and 2016. While the commune names are not available in the data, a commune-ID is supplied. The commune-ID allows us generating three-year panel data. For our empirical analysis, we need information on (i) commune emigration figures (left hand variable), (ii) data on the occurrence of natural disasters, and (iii) commune characteristics as control variables.

The VARHS contains only unilateral information on emigration. Thus, the number of total emigrants from each included commune is available. However, there is no information on the destination commune of emigrants. ${ }^{6}$

For our subsequent empirical analysis we also need information on the occurrence of climate-related natural disasters. While the VARHS data contains data on the occurrence of droughts, floods and typhoons on the commune-level, one might argue that using this data is problematic as the respondents to the questionnaire might justify high emigration numbers by over-reporting disaster events. In order to rule out this potential problem one might think of combining the VARHS data with geo-referenced data from disaster databases. However, as the data contain only anonymous commune-IDs rather than commune names, doing so is impossible. We therefore have to rely on the disaster information reported in the VARHS data itself. However, as migration figures and disaster occurrence are parts of different chapters of the survey and most likely answered by different officials, we do not expect systematic biases to occur. The data contains information whether a certain type of disaster occurred in the year preceding the survey or the two years preceding the survey. For both time perspectives and for each disaster type (e.g. droughts, floods and typhoons) we code dummy variables. Moreover, the respondents were asked to judge whether disasters of each type became worse over the decade before the survey was conducted. Again, we code a dummy variable for each of the three types of disasters.

In order to estimate a well-specified empirical model we also need to control for relevant commune characteristics. Our choice of control variables follows the related literature, however, is naturally restricted by the availability of these variables in the VARHS data. An often employed theoretical foundation for empirical specifications of migration studies is the Utility Maximization Approach (see e.g. Borjas (1987) and Beine and Parsons (2015), or Dallmann and Millock (2017)). Basically, this approach leads to a gravity model in which four sorts of migration determinants have to be considered: the wage differential between destination and origin, the conditions at the place of origin, the conditions at possible destinations and migration costs between both places. Due to the fact that the dataset contains only unilateral migration information, we have to refrain from estimating a gravity model. However, we still can base the choice of our variables to some extent on the Utilization Maximization Approach. In order to cover wages we include average annual income per capita, which is available in the data. Moreover, we control for commune population size. We also control for the number of firms with at least 10 employees. In order to control for education, we include the percentage of students which graduated from secondary schools and the percentage of students which graduated from junior high schools and continued to senior high

\footnotetext{
${ }^{6}$ As the emigration target is unknown, it cannot be ruled out that the reported number of emigrants also includes international migration. However, the overwhelming majority of emigrants moves within Vietnam.
} 
schools. We further assume that all other relevant commune characteristics are constant over the sample horizon. Under this assumption we can correct for unobserved heterogeneity by including fixed effects in our later applied estimation approach. The fixed effects also controls for existing migration networks and the migration history of the included communes. Table 1 delivers some descriptive statistics on the employed variables.

\section{Empirical Approach and Estimation Results}

\section{Empirical Approach}

In order to find out whether recently occurring natural disasters or disaster trends over the last decade have a systematic impact on migration patterns we run two-way fixed effects panel models of the type

$$
M_{i, t}=\alpha_{i}+\beta_{t}+\gamma \cdot D_{i, t}+\theta \cdot C_{i, t}+\epsilon_{i, t}
$$

where $M_{i, t}$ is the number of emigrants from region $i$ at time $t, D$ is a measure of the occurrence of (a certain type of) natural disasters (in our case a dummy variable for a disaster occurring in the last, the last two years or disasters becoming more severe over the last decade), $C$ is a vector of control variables and $\epsilon$ stands for the unexplained residual. The parameters to be estimated are the commune-fixed effects $\alpha_{i}$, the time-fixed effects $\beta_{t}$, the vector $\theta$ (i.e. the influence of the control variables) and $\gamma$, the parameter of central interest, measuring the impact of the disaster variable on emigration flows. The commune-fixed effect controls for time-constant unobserved heterogeneity.

Obviously, our measures of emigration (i.e. total emigrants, permanent emigrants and temporary emigrants) are count variables. Moreover, as we conduct our analysis on the

Table 1 Descriptive statistics (1200 observations)

\begin{tabular}{|c|c|c|c|c|}
\hline Variables & Mean & Std. Dev. & Min & $\operatorname{Max}$ \\
\hline Average income (Unit: 000 VND) & 17263.55 & 9395.83 & 146 & 52000 \\
\hline Population (Unit: persons) & 8259.18 & 4113.49 & 518 & 24775 \\
\hline Number of firms (Unit: firms) & 19.02 & 85.40 & 0 & 1200 \\
\hline Students continuing to senior high school (Unit: percent) & 87.02 & 18.92 & 0 & 100 \\
\hline Student finishing secondary school (Unit: percent) & 95.18 & 13.92 & 0 & 100 \\
\hline Total emigration (Unit: persons) & 193.73 & 212.12 & 0 & 2387 \\
\hline Total permanent emigration (Unit: persons) & 108.02 & 114.23 & 0 & 1300 \\
\hline Total temporary emigration (Unit: persons) & 85.71 & 154.52 & 0 & 2134 \\
\hline Droughts in last year $(1=$ yes, $0=$ no $)$ & .40 & .49 & 0 & 1 \\
\hline Droughts in last two years $(1=$ yes, $0=$ no $)$ & .46 & .50 & 0 & 1 \\
\hline Droughts worse over last decade $(1=$ yes, $0=$ no $)$ & .32 & .47 & 0 & 1 \\
\hline Floods in last year $(1=$ yes, $0=$ no $)$ & .30 & .46 & 0 & 1 \\
\hline Floods in last two years $(1=$ yes, $0=$ no $)$ & .37 & .48 & 0 & 1 \\
\hline Floods worse over last decade $(1=$ yes, $0=$ no $)$ & .20 & .40 & 0 & 1 \\
\hline Typhoons in last year $(1=$ yes, $0=$ no $)$ & .27 & .45 & 0 & 1 \\
\hline Typhoons in last two years $(1=$ yes, $0=$ no $)$ & .33 & .47 & 0 & 1 \\
\hline Typhoons worse over last decade $(1=$ yes, $0=$ no $)$ & .19 & .39 & 0 & 1 \\
\hline
\end{tabular}


commune-level, the count values are not too large so that ordinary least squares estimations might be inappropriate. In order to account for these properties typically Poisson regressions are used. However, as these regressions often suffer from over- or underdispersion we apply a generalization of the Poisson regressions approach and estimate negative binomial regressions (Allison 2009).

A major issue in estimating the effect of climate or natural disasters on migration is the so-called overcontrolling problem (Dell et al. 2014; Berlemann and Steinhardt 2017). Whenever we aim at measuring the full effect of climate or natural disasters on migration, control variables which themselves might be affected by climate or disasters should not be part of the regression equation. Whenever they are added nevertheless, as it is often done in the related literature, we measure a partial rather than the total effect (Beine and Parsons 2017). In order to deal with this problem adequately we estimate a two-way fixed effects model without any additional (and possibly endogenous) control variables in our main estimation specification. However, we also show the results we derive under the inclusion of control variables.

To further check the robustness of our results we repeated all regressions using the (scaled) Ordinary Least Squares (OLS) Method. While our left-hand variable is a count variable, it is well-known that the distribution of larger count variables converges against the normal distribution. Thus, estimating the model using OLS is adequate under these circumstances. We therefore first transformed the left-hand variable by exchanging all zero values against the value of one. We then took to log of the migration variable and reestimated all models.

\section{Droughts}

We start out with studying the effect of droughts on total emigration numbers. The referring estimation results are presented in Table 2.

Column one of Table 2 shows the results for recently occurring floods. We find significantly higher total emigration counts for communes which experienced a drought event throughout the year before the survey was conducted as compared to those which were not affected by drought. The average marginal effect amounts to 35 emigrants and is thus sizeable. A similar effect results for communes which experienced droughts throughout the two years preceding the survey (see column 3 ). Here, the average marginal effect amounts to 38 emigrants. And even when considering the long-run perspective by focusing on communes in which droughts became more severe over the decade before the survey was conducted, we find significantly higher emigration counts (column 5). On average, 55 individuals emigrate from these communes. As columns 2, 4 and 6 indicate, the effects do not differ qualitatively when we include control variables. We also derive qualitatively the same results when employing scaled OLS rather than negative binomial regressions (the referring estimation results are reported in the Appendix A).

Our findings indicate that droughts cause significant emigration from the affected communes, both in the short- and the long-run. As outlined earlier, the yet only existing evidence on the migration effects of droughts in Vietnam comes from Koubi et al. (2016a, b). Both papers are based on the same survey and find that slow-onset disasters tend to decrease emigration from the affected communes, at least when excluding control variables from the regression approach. As droughts also belong to the group of slow-onset disasters, our results tend to contradict the findings by Koubi et al. (2016a, b). However, as these studies do not focus explicitly on droughts, but in more general, study slow-onset disasters and thus also include other disasters such as desertification or salinization, the results are not 
Table 2 Emigration and Droughts (Negative Binomial regression results)

Dependent variable:

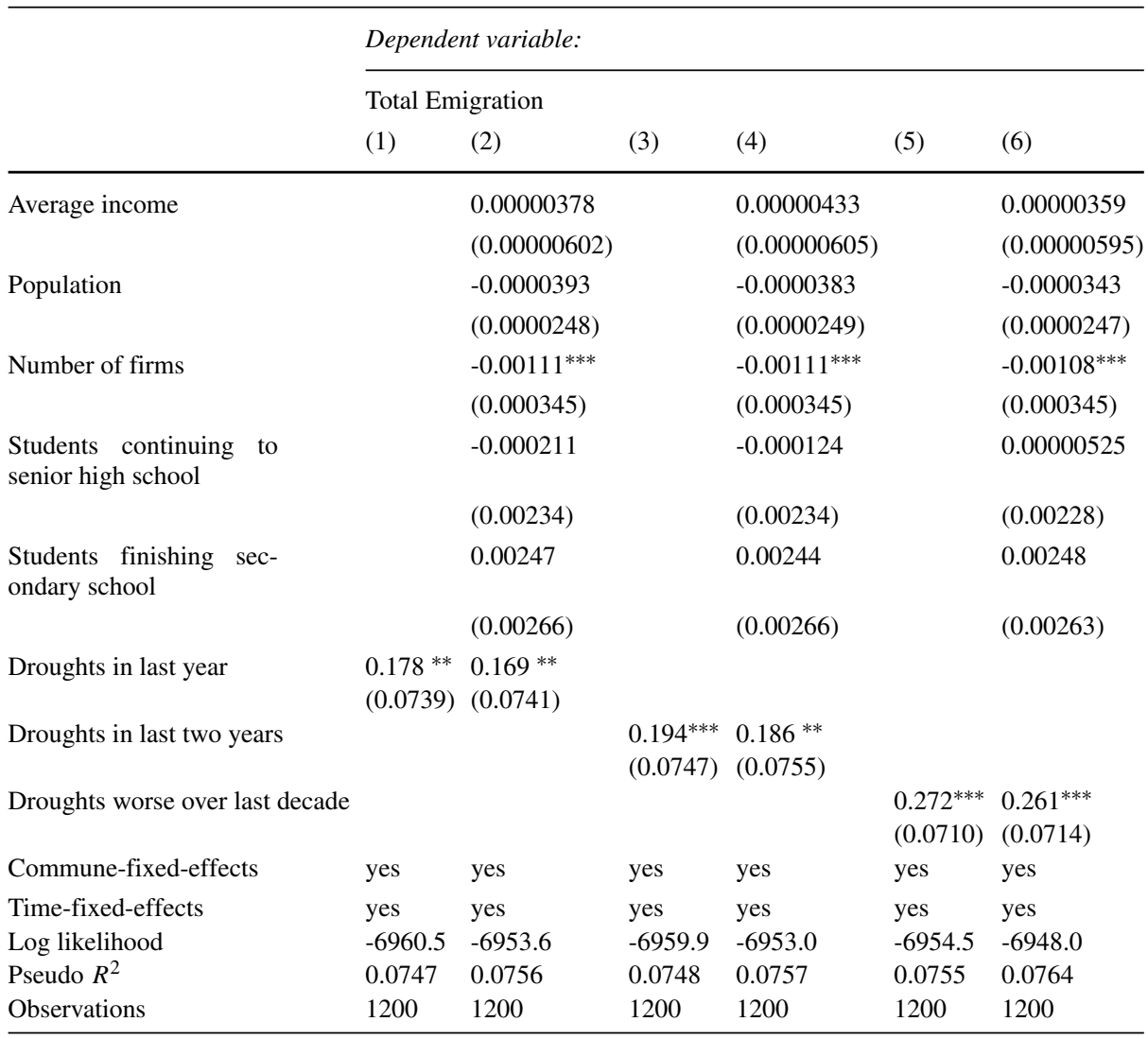

Standard errors in parentheses, ${ }^{*} \mathrm{p}<0.1 ;{ }^{* *} \mathrm{p}<0.05 ;{ }^{* * *} \mathrm{p}<0.01$

completely comparable. Our findings are in line with the results reported in Dallmann and Millock (2017) for India, where droughts tend to increase inter-state migration figures.

As we have disaggregated data for permanent and temporary emigration we can study migration decisions in the context of natural disasters in more detail. In order to do so we repeat all estimations for temporary and permanent migration figures. The referring estimation results are reported in Tables 3 and $4 .{ }^{7}$ Interestingly enough, in the short-run droughts tend to affect primarily temporary emigration. While recently occurring droughts significantly increases temporary emigration from the affected communes, no such effect can be detected for permanent emigration. However, when droughts became more severe over the preceding decade, both temporary and permanent emigration is significantly higher. This pattern points into the direction that drought-affected individuals initially do not plan to move out of the affected communes permanently. However, when there are indications that droughts will happen systematically more often in the future, a significant number of individuals moves permanently to other communes.

\footnotetext{
${ }^{7}$ As it is reported in the Appendix A in detail, the results remain qualitatively stable when using scaled OLS rather that negative binomial regressions.
} 
Table 3 Temporary Emigration and Droughts (Negative Binomial regression results)

Dependent variable:

Temporary Emigration
(1)
(2)
(3)
(4)
(5)
(6)

\begin{tabular}{lll}
\hline Droughts in last year & $0.603^{* * *}$ & $0.581^{* * *}$ \\
& $(0.199)$ & $(0.198)$
\end{tabular}

Droughts in last two years

$\begin{array}{ll}0.688^{* * *} & 0.655^{* * *} \\ (0.198) & (0.198)\end{array}$

Droughts worse over last decade

\begin{tabular}{llllll} 
& & & & $0.366^{*}$ & $0.348^{*}$ \\
& & & & $(0.196)$ & $(0.195)$ \\
yes & yes & yes & yes & yes & yes \\
yes & yes & yes & yes & yes & yes \\
no & yes & no & yes & no & yes \\
-5652.0 & -5646.7 & -5650.3 & -5645.3 & -5656.6 & -5651.0 \\
0.0600 & 0.0609 & 0.0603 & 0.0612 & 0.0593 & 0.0602 \\
1200 & 1200 & 1200 & 1200 & 1200 & 1200 \\
\hline
\end{tabular}

Included controls: average income, population, number of firms, students continuing to senior high school, students finishing secondary school

Standard errors in parentheses, ${ }^{*} \mathrm{p}<0.1 ;{ }^{* *} \mathrm{p}<0.05 ;{ }^{* * *} \mathrm{p}<0.01$

Table 4 Permanent Emigration and Droughts (Negative Binomial regression results)

\section{Dependent variable:}

Permanent Emigration
(1)
(2)
(3)
(4)
(5)
(6)

\begin{tabular}{lll}
\hline Droughts in last year & 0.0266 & 0.00916 \\
& $(0.0772)$ & $(0.0772)$
\end{tabular}

Droughts in last two years

$\begin{array}{ll}0.0576 & 0.0455 \\ (0.0766) & (0.0770)\end{array}$

Droughts worse over last decade

\begin{tabular}{llllll} 
& & & & $0.197^{* * *}$ & $0.184^{* *}$ \\
& & & & $(0.0733)$ & $(0.0740)$ \\
yes & yes & yes & yes & yes & yes \\
yes & yes & yes & yes & yes & yes \\
no & yes & no & yes & no & yes \\
-6293.2 & -6287.5 & -6292.9 & -6287.3 & -6288.4 & -6283.3 \\
0.0778 & 0.0786 & 0.0778 & 0.0787 & 0.0785 & 0.0792 \\
1200 & 1200 & 1200 & 1200 & 1200 & 1200 \\
\hline
\end{tabular}

Included controls: average income, population, number of firms, students continuing to senior high school, students finishing secondary school

Standard errors in parentheses, ${ }^{*} \mathrm{p}<0.1 ;{ }^{* *} \mathrm{p}<0.05 ;{ }^{* * *} \mathrm{p}<0.01$ 


\section{Floods}

In the next step of our analysis we study the case of flood events. Again we start out with the effect of floods on total emigration counts. The referring estimation results are presented in Table 5. The results indicate that floods tend to have no significant effect on total emigration in the short-run, regardless of whether control variables are included or not. This finding is in line with the finding by Bohra - Mishra et al. (2014) for Indonesia and Gray and Mueller (2012) for Bangladesh that episodically occurring disasters tend to have little effect on emigration.

However, while a single flood which occurred in the recent past seems not to spur emigration from the affected commune, an increasing flood risk in general seems to increase emigration flows. ${ }^{8}$ The average marginal effect in communes where flood risk increased over the preceding decade amounts to 43 emigrants. We thus find supporting evidence for the results reported in Dun (2011) that especially recurring flood events tend to increase emigration in Vietnam. Our findings are also in line with the finding of Koubi et al. (2016a, b) that increased risk from sudden-onset events (such as floods) tend to increase emigration in Vietnam.

The estimation results for temporary and permanent emigration are summarized in Tables 6 and 7. Different from drought events, recent floods do not cause significant temporary emigration, regardless of whether we include control variables or not. For both short-term indicators we do not find a significant temporary emigration effect. The same holds true for increasing flood risk over the last decade. Only when running scaled OLS regressions rather than negative binomial regressions temporary migration figures are affected significantly for worsening flood trends. However, altogether there is little evidence that floods cause temporary migration.

If the affected population reacts at all to episodically occurring flood events, they tend to move out of the affected areas permanently. As Table 7 reveals, only the coefficient for flood events occurring in the two years before the survey was conducted turns out to be significant. However, as this effect becomes insignificant when estimating a scaled OLS model rather than a negative binomial, ${ }^{9}$ this evidence must be judged as rather weak. One might conclude that floods tend to have little effect on permanent emigration in the shortrun. However, the results are different when floods in general became more severe over the last decade. Whenever risks from floods increase this goes along with increased permanent emigration figures.

\section{Typhoons}

Finally, we turn to the case of typhoons. The estimation results for total emigration, which are displayed in Table 8, indicate that neither typhoons which occurred recently nor worsening typhoon trends over the last decade have a significant effect on total emigration figures. Again these results hold even when including control variables. ${ }^{10}$ Our findings are in line with the finding of Paul (2005), who fails to find a significant emigration effect for a disastrous tornado which occurred in 2004 in Bangladesh. However, our results do not fit to the

\footnotetext{
${ }^{8}$ These results are confirmed when estimating scaled OLS regressions rather than negative binomials. See the results reported in the Appendix B.

${ }^{9}$ The referring results are reported in the Appendix B.

${ }^{10}$ We find qualitatively the same results when running scaled OLS regressions; see the Appendix C for the referring results.
} 
Table 5 Total Emigration and Floods (Negative Binomial regression results)

Dependent variable:

Total Emigration

(1) (2) (3) (4) (5) (6)

\begin{tabular}{|c|c|c|c|c|c|c|}
\hline \multirow[t]{2}{*}{ Average income } & & 0.00000436 & & 0.00000395 & & 0.00000426 \\
\hline & & $(0.00000603)$ & & $(0.00000604)$ & & $(0.00000603)$ \\
\hline \multirow[t]{2}{*}{ Population } & & -0.0000380 & & -0.0000379 & & $-0.0000406^{*}$ \\
\hline & & $(0.0000246)$ & & $(0.0000246)$ & & $(0.0000242)$ \\
\hline \multirow[t]{2}{*}{ Number of firms } & & $-0.00114^{* * *}$ & & $-0.00115^{* * *}$ & & $-0.00117^{* * *}$ \\
\hline & & $(0.000339)$ & & $(0.000336)$ & & $(0.000334)$ \\
\hline \multirow{2}{*}{$\begin{array}{l}\text { Percentage of student } \\
\text { continue to senior high } \\
\text { school }\end{array}$} & & -0.000626 & & -0.000751 & & -0.000797 \\
\hline & & $(0.00233)$ & & $(0.00232)$ & & $(0.00230)$ \\
\hline \multirow{2}{*}{$\begin{array}{l}\text { Percentage of student } \\
\text { finishing secondary } \\
\text { school }\end{array}$} & & 0.00266 & & 0.00264 & & 0.00264 \\
\hline & & $(0.00265)$ & & $(0.00267)$ & & $(0.00259)$ \\
\hline \multirow[t]{2}{*}{ Floods in last year } & 0.0658 & 0.0621 & & & & \\
\hline & $(0.0793)$ & $(0.0799)$ & & & & \\
\hline \multirow[t]{2}{*}{ Floods in last two years } & & & 0.106 & 0.104 & & \\
\hline & & & $(0.0721)$ & $(0.0727)$ & & \\
\hline \multirow[t]{2}{*}{ Floods worse over last decade } & & & & & $0.211^{* *}$ & $0.220^{* * *}$ \\
\hline & & & & & $(0.0843)$ & $(0.0848)$ \\
\hline Commune-fixed-effects & yes & yes & yes & yes & yes & yes \\
\hline Time-fixed-effects & yes & yes & yes & yes & yes & yes \\
\hline Log likelihood & -6964.0 & -6956.7 & -6963.1 & -6955.8 & -6960.1 & -6952.4 \\
\hline Pseudo $R^{2}$ & 0.0743 & 0.0752 & 0.0744 & 0.0753 & 0.0748 & 0.0758 \\
\hline Observations & 1200 & 1200 & 1200 & 1200 & 1200 & 1200 \\
\hline
\end{tabular}

Standard errors in parentheses, ${ }^{*} \mathrm{p}<0.1 ;{ }^{* *} \mathrm{p}<0.05 ;{ }^{* * *} \mathrm{p}<0.01$

findings reported in the study by Gröger and Zylberberg (2016) for Vietnam. As explained earlier in detail, this study finds significant emigration from Vietnamese regions which were hit by typhoon Ketsana in 2009. However, it should be noted that Ketsana was the by far most severe typhoon which made landfall in Vietnam over the period of 2009 to 2015. Thus, it is well possible that only the most severe typhoons cause migration. As we cannot distinguish between storms of different severity in our sample we cannot study this issue in more detail.

Not too surprising, we also fail to find any significant effect of typhoons on temporary or permanent migration, regardless of whether we include control variables or not. The results are displayed in Tables 9 and $10 .^{11}$

\footnotetext{
${ }^{11}$ Again this result turns out to be stable when using scaled OLS rather than negative binomial regressions. See Appendix $\mathrm{C}$ for a documentation of the results.
} 
Table 6 Temporary Emigration and Floods (Negative Binomial regression results)

Dependent variable:

Temporary Emigration

(1)

(2)

(3)

(4)

(5)

(6)

Floods in last year

$\begin{array}{ll}0.0976 & 0.115 \\ (0.216) & (0.215)\end{array}$

Floods in last two years

$0.0908 \quad 0.109$

(0.202) (0.202)

Floods worse over last decade

\begin{tabular}{llllll} 
& & & & 0.320 & 0.339 \\
yes & yes & yes & yes & yes & yes \\
yes & yes & yes & yes & yes & yes \\
no & yes & no & yes & no & yes \\
-5659.3 & -5653.4 & -5659.3 & -5653.4 & -5657.9 & -5651.8 \\
0.0588 & 0.0598 & 0.0588 & 0.0598 & 0.0591 & 0.0601 \\
1200 & 1200 & 1200 & 1200 & 1200 & 1200 \\
\hline
\end{tabular}

Included controls: average income, population, number of firms, students continuing to senior high school, students finishing secondary school

Standard errors in parentheses, ${ }^{*} \mathrm{p}<0.1 ;{ }^{* *} \mathrm{p}<0.05 ;{ }^{* * *} \mathrm{p}<0.01$

\section{Joint Estimation Results}

As communities might be hit by different sorts of disasters in the same year, we complete our estimations by delivering regression results under the inclusion of disaster indicators

Table 7 Permanent Emigration and Floods (Negative Binomial regression results)

\section{Dependent variable:}

Permanentl Emigration
(1)
(2)
(3)
(4)
(5)
(6)

\begin{tabular}{lll}
\hline Floods in last year & 0.0366 & 0.0337 \\
& $(0.0781)$ & $(0.0787)$
\end{tabular}

Floods in last two years

$\begin{array}{ll}0.139^{*} & 0.133^{*} \\ (0.0711) & (0.0715)\end{array}$

Floods worse over last decade

\begin{tabular}{llllll} 
& & & & $0.191^{* *}$ & $0.192^{* *}$ \\
& & & & $(0.0905)$ & $(0.0909)$ \\
yes & yes & yes & yes & yes & yes \\
yes & yes & yes & yes & yes & yes \\
no & yes & no & yes & no & yes \\
-6293.1 & -6287.4 & -6291.1 & -6285.6 & -6289.9 & -6284.1 \\
0.0778 & 0.0786 & 0.0781 & 0.0789 & 0.0783 & 0.0791 \\
1200 & 1200 & 1200 & 1200 & 1200 & 1200 \\
\hline
\end{tabular}

Included controls: average income, population, number of firms, students continuing to senior high school, students finishing secondary school

Standard errors in parentheses, ${ }^{*} \mathrm{p}<0.1 ;{ }^{* *} \mathrm{p}<0.05 ;{ }^{* * *} \mathrm{p}<0.01$ 
Table 8 Total Emigration and Typhoons (Negative Binomial regression results)

Dependent variable:

Total Emigration

(1)

(2)

(3)

(4)

(5)

(6)

\begin{tabular}{|c|c|c|c|c|c|c|}
\hline \multicolumn{2}{|l|}{ Average income } & \multicolumn{2}{|l|}{$\begin{array}{l}0.00000462 \\
(0.00000602)\end{array}$} & \multicolumn{2}{|l|}{$\begin{array}{l}0.00000465 \\
(0.00000603)\end{array}$} & $\begin{array}{l}0.00000461 \\
(0.00000600)\end{array}$ \\
\hline \multicolumn{2}{|l|}{ Population } & $\begin{array}{l}-0.0000394 \\
(0.0000245)\end{array}$ & & $\begin{array}{l}-0.0000390 \\
(0.0000245)\end{array}$ & & $\begin{array}{l}-0.0000386 \\
(0.0000246)\end{array}$ \\
\hline \multicolumn{2}{|l|}{ Number of firms } & $\begin{array}{l}-0.00113^{* * *} \\
(0.000341)\end{array}$ & & $\begin{array}{l}-0.00113^{* * *} \\
(0.000342)\end{array}$ & & $\begin{array}{l}-0.00112^{* * *} \\
(0.000340)\end{array}$ \\
\hline \multirow{2}{*}{\multicolumn{2}{|c|}{$\begin{array}{l}\text { Percentage of student } \\
\text { continue to senior } \\
\text { high school }\end{array}$}} & -0.000504 & & -0.000519 & & -0.000492 \\
\hline & & $(0.00234)$ & & $(0.00233)$ & & $(0.00235)$ \\
\hline \multicolumn{2}{|l|}{$\begin{array}{l}\text { Percentage of student } \\
\text { finishing secondary } \\
\text { school }\end{array}$} & 0.00269 & & 0.00271 & & 0.00268 \\
\hline Typhoons in last year & $\begin{array}{l}-0.00681 \\
(0.0787)\end{array}$ & $\begin{array}{l}(0.00265) \\
-0.00522 \\
(0.0788)\end{array}$ & & $(0.00263)$ & & $(0.00264)$ \\
\hline $\begin{array}{l}\text { Typhoons in last } \\
\text { two years }\end{array}$ & & & $\begin{array}{l}-0.0444 \\
(0.0766)\end{array}$ & $\begin{array}{l}-0.0439 \\
(0.0768)\end{array}$ & & \\
\hline $\begin{array}{l}\text { Typhoons worse } \\
\text { over last decade }\end{array}$ & & & & & $\begin{array}{l}0.0775 \\
(0.0844)\end{array}$ & $\begin{array}{l}0.0682 \\
(0.0851)\end{array}$ \\
\hline $\begin{array}{l}\text { Commune-fixed- } \\
\text { effects }\end{array}$ & yes & yes & yes & yes & yes & yes \\
\hline Time-fixed-effects & yes & yes & yes & yes & yes & yes \\
\hline Log likelihood & -6964.4 & -6957.2 & -6964.2 & -6956.9 & -6963.9 & -6956.7 \\
\hline Pseudo $R^{2}$ & 0.0742 & 0.0752 & 0.0742 & 0.0752 & 0.0743 & 0.0752 \\
\hline Observations & 1200 & 1200 & 1200 & 1200 & 1200 & 1200 \\
\hline
\end{tabular}

Standard errors in parentheses, ${ }^{*} \mathrm{p}<0.1 ;{ }^{* *} \mathrm{p}<0.05 ;{ }^{* * *} \mathrm{p}<0.01$

for all three disaster types at the same time. In order to gain a systematic picture we study the reaction to disasters which happened in the year before the survey was conducted, to disasters which occurred in the two years before the survey was conducted and to the 10year-disaster trends. The estimation results are displayed in Table 11.

Basically, the estimation results confirm our previous findings. We find the most systematic effect for droughts. Whenever droughts occurred in the previous or over the previous two years, emigration outflows from the referring commune are systematically higher than without drought events. The same holds true for communes where droughts in general became more severe over the last decade. For flood events we find a systematic effect only for a worsening long-run trend. No effect at all occurs for typhoons.

\section{Summary and Conclusions}

The main goal of this paper is to test whether different sorts of natural disasters are push factors of migration. Based on panel survey data from the most disaster-prone countries 
Table 9 Temporary Emigration and Typhoons (Negative Binomial regression results)

Dependent variable:

Temporary Emigration
(1)
(2)
(3)
(4)
(5)
(6)

Typhoons in last year

$\begin{array}{ll}0.174 & 0.166 \\ (0.212) & (0.210)\end{array}$

Typhoons in last two years

$0.198 \quad 0.188$

$(0.207) \quad(0.205)$

Typhoons worse over last decade

\begin{tabular}{llllll} 
& & & & 0.0546 & 0.0456 \\
& & & & $(0.243)$ & $(0.238)$ \\
yes & yes & yes & yes & yes & yes \\
yes & yes & yes & yes & yes & yes \\
no & yes & no & yes & no & yes \\
-5659.0 & -5653.1 & -5658.8 & -5653.0 & -5659.4 & -5653.6 \\
0.0589 & 0.0599 & 0.0589 & 0.0599 & 0.0588 & 0.0598 \\
1200 & 1200 & 1200 & 1200 & 1200 & 1200 \\
\hline
\end{tabular}

Included controls: average income, population, number of firms, students continuing to senior high school, students finishing secondary school

Standard errors in parentheses, ${ }^{*} \mathrm{p}<0.1 ;{ }^{* *} \mathrm{p}<0.05 ;{ }^{* * *} \mathrm{p}<0.01$

of the world, Vietnam, we run two-way fixed effects regressions on the commune-level. We find that especially droughts push parts of the population out of the affected regions, both in the short- and in the long-run. Communes where flood events became either more

Table 10 Permanent Emigration and Typhoons (Negative Binomial regression results)

\section{Dependent variable:}

\section{Permanent Emigration}
(1)
(2)
(3)
(4)
(5)

(6)

Typhoons in last year

$\begin{array}{ll}-0.0362 & -0.0334 \\ (0.0845) & (0.0839)\end{array}$

Typhoons in last two years

$\begin{array}{ll}-0.0366 & -0.0358 \\ (0.0829) & (0.0826)\end{array}$

Typhoons worse over last decade

\begin{tabular}{llllll} 
& & & & 0.0808 & 0.0840 \\
& & & & $(0.0856)$ & $(0.0854)$ \\
yes & yes & yes & yes & yes & yes \\
yes & yes & yes & yes & yes & yes \\
no & yes & no & yes & no & yes \\
-6293.1 & -6287.4 & -6293.1 & -6287.4 & -6292.7 & -6286.9 \\
0.0778 & 0.0786 & 0.0778 & 0.0786 & 0.0779 & 0.0787 \\
1200 & 1200 & 1200 & 1200 & 1200 & 1200 \\
\hline
\end{tabular}

Included controls: average income, population, number of firms, students continuing to senior high school, students finishing secondary school

Standard errors in parentheses, ${ }^{*} \mathrm{p}<0.1 ;{ }^{* *} \mathrm{p}<0.05 ;{ }^{* * *} \mathrm{p}<0.01$ 
Table 11 Total Emigration and Natural Hazards (Negative Binomial regression results)

Dependent variable:

Total Emigration
(1)
(2)
(3)
(4)
(5)
(6)

\begin{tabular}{|c|c|c|c|c|c|c|}
\hline Average income & & $\begin{array}{l}0.00000367 \\
(0.00000604)\end{array}$ & & $\begin{array}{l}0.00000384 \\
(0.00000610)\end{array}$ & & $\begin{array}{l}0.00000341 \\
(0.00000600)\end{array}$ \\
\hline \multirow[t]{2}{*}{ Population } & & -0.0000382 & & -0.0000362 & & -0.0000371 \\
\hline & & $(0.0000250)$ & & $(0.0000250)$ & & $(0.0000243)$ \\
\hline \multirow{2}{*}{\multicolumn{2}{|c|}{ Number of firms }} & $-0.00112^{* * *}$ & & $-0.00112^{* * *}$ & & $-0.00113^{* * *}$ \\
\hline & & $(0.000344)$ & & $(0.000342)$ & & $(0.000343)$ \\
\hline \multirow{2}{*}{$\begin{array}{l}\text { Students continuing to senior } \\
\text { high school }\end{array}$} & & -0.000322 & & -0.000382 & & -0.000274 \\
\hline & & $(0.00234)$ & & $(0.00232)$ & & $(0.00230)$ \\
\hline \multirow{2}{*}{$\begin{array}{l}\text { Student finishing secondary } \\
\text { school }\end{array}$} & & 0.00244 & & 0.00246 & & 0.00246 \\
\hline & & $(0.00267)$ & & $(0.00267)$ & & $(0.00259)$ \\
\hline \multirow[t]{2}{*}{ Droughts in last year } & $0.174^{* *}$ & $0.166^{* *}$ & & & & \\
\hline & $(0.0751)$ & $(0.0755)$ & & & & \\
\hline \multirow[t]{2}{*}{ Floods in last year } & 0.0431 & 0.0396 & & & & \\
\hline & $(0.0850)$ & $(0.0857)$ & & & & \\
\hline \multirow[t]{2}{*}{ Typhoons in last year } & -0.0354 & -0.0317 & & & & \\
\hline & $(0.0836)$ & $(0.0837)$ & & & & \\
\hline \multirow[t]{2}{*}{ Droughts in last two years } & & & $0.188^{* *}$ & $0.178^{* *}$ & & \\
\hline & & & $(0.0757)$ & $(0.0768)$ & & \\
\hline \multirow[t]{2}{*}{ Floods in last two years } & & & 0.0897 & 0.0883 & & \\
\hline & & & $(0.0762)$ & $(0.0767)$ & & \\
\hline \multirow[t]{2}{*}{ Typhoons in last two years } & & & -0.0826 & -0.0807 & & \\
\hline & & & $(0.0801)$ & $(0.0805)$ & & \\
\hline \multirow{2}{*}{$\begin{array}{l}\text { Droughts worse over last } \\
\text { decade }\end{array}$} & & & & & $0.252^{* * *}$ & $0.238^{* * *}$ \\
\hline & & & & $(0.0772)$ & $(0.0783)$ & \\
\hline \multirow{2}{*}{$\begin{array}{l}\text { Floods worse over last } \\
\text { decade }\end{array}$} & & & & & $0.149^{*}$ & $0.168^{*}$ \\
\hline & & & & & $(0.0909)$ & $(0.0952)$ \\
\hline \multirow{2}{*}{$\begin{array}{l}\text { Typhoons worse over last } \\
\text { decade }\end{array}$} & & & & & -0.0887 & -0.102 \\
\hline & & & & & $(0.0947)$ & $(0.0952)$ \\
\hline Commune-fixed-effects & yes & yes & yes & yes & yes & yes \\
\hline Time-fixed-effects & yes & yes & yes & yes & yes & yes \\
\hline Log likelihood & -6960.3 & -6953.4 & -6958.5 & -6951.6 & -6952.8 & -6945.8 \\
\hline Pseudo $R^{2}$ & 0.0748 & 0.0757 & 0.0750 & 0.0759 & 0.0758 & 0.0767 \\
\hline Observations & 1200 & 1200 & 1200 & 1200 & 1200 & 1200 \\
\hline
\end{tabular}

Standard errors in parentheses, ${ }^{*} \mathrm{p}<0.1 ;{ }^{* *} \mathrm{p}<0.05 ;{ }^{* * *} \mathrm{p}<0.01$

frequent or more severe of the last decade also experience significantly more emigration. No systematic effect could be detected for typhoons. One might speculate why typhoons have less effect on migration figures as droughts and floods, at least in the case of Vietnam. One possible explanation might be that due to Vietnam's geography and its long coastline, there are few places where typhoons cannot occur at all. In general typhoons, as compared 
to floods and droughts, exhibit a greater variability in the places where they occur. Against this background and in the light of considerable migration costs, individuals might refrain from considering emigration in the case of typhoons.

According to the earlier discussed predictions, large parts of Vietnam will experience ongoing climate change. This will most likely further increase the frequency and the severity of climate-related disasters. The pressure to emigrate from the most affected regions will further increase and might cause severe problems not only in the regions losing population but also in the likely target regions. In order to keep the negative consequences of disasterinduced migration as low as possible more research on the likely internal migration flows is urgently necessary.

Funding Information Open Access funding provided by Projekt DEAL.

Open Access This article is licensed under a Creative Commons Attribution 4.0 International License, which permits use, sharing, adaptation, distribution and reproduction in any medium or format, as long as you give appropriate credit to the original author(s) and the source, provide a link to the Creative Commons licence, and indicate if changes were made. The images or other third party material in this article are included in the article's Creative Commons licence, unless indicated otherwise in a credit line to the material. If material is not included in the article's Creative Commons licence and your intended use is not permitted by statutory regulation or exceeds the permitted use, you will need to obtain permission directly from the copyright holder. To view a copy of this licence, visit http://creativecommonshorg/licenses/by/4.0/.

\section{Appendix: A Droughts}

Table 12 Total Emigration and Droughts (OLS regression results)

Dependent variable:

Log of Total Emigration

(1) (2)

Average income

Population

Number of firms

Students continuing to

senior high school

Students finishing sec-

ondary school

Droughts in last year

$0.232^{* * *} \quad 0.215^{* *}$

(0.0828)

0.00000284
$(0.00000719)$
-0.0000435
$(0.0000416)$
$-0.00133^{* * *}$
$(0.000501)$
-0.00232

$(0.00252)$

0.00492

(0.00327)

Droughts in last two years

Droughts worse over last decade

\begin{tabular}{lllllll} 
& & & & & & \\
Commune-fixed-effects & yes & yes & yes & yes & yes & yes \\
Time-fixed-effects & yes & yes & yes & yes & yes & yes \\
Observations & 1200 & 1200 & 1200 & 1200 & 1200 & 1200 \\
\hline
\end{tabular}

(6)

0.00000208
$(0.00000712)$
-0.0000418
$(0.0000397)$
$-0.00131^{* * *}$
$(0.000496)$
-0.00185

(0.00257)

0.00470

(0.00331)

$\begin{array}{ll}0.250^{* * *} & 0.230^{* * *} \\ (0.0886) & (0.0880)\end{array}$

(0.0886) (0.0880)

Standard errors in parentheses, ${ }^{*} \mathrm{p}<0.1 ;{ }^{* *} \mathrm{p}<0.05 ;{ }^{* * *} \mathrm{p}<0.01$ 
Table 13 Temporary Emigration and Droughts (OLS regression results)

Dependent variable:

Log of Temporary Emigration

(1)

(2)

(3)

(4)

(5)

(6)

Droughts in last year

$\begin{array}{ll}0.514^{* * *} & 0.502^{* * *} \\ (0.172) & (0.174)\end{array}$

Droughts in last two years

$\begin{array}{ll}0.660^{* * *} & 0.639^{* * *} \\ (0.178) & (0.179)\end{array}$

Droughts worse over last decade

\begin{tabular}{llll} 
& & $0.299^{*}$ & $0.288^{*}$ \\
& & $(0.161)$ & $(0.161)$ \\
yes & yes & yes & yes \\
yes & yes & yes & yes \\
no & yes & no & yes \\
1200 & 1200 & 1200 & 1200 \\
\hline
\end{tabular}

Included controls: average income, population, number of firms, students continuing to senior high school, students finishing secondary school

Standard errors in parentheses, ${ }^{*} \mathrm{p}<0.1 ;{ }^{* *} \mathrm{p}<0.05 ;{ }^{* * *} \mathrm{p}<0.01$

Table 14 Permanent Emigration and Droughts (OLS regression results)

\section{Dependent variable:}

Log of Permanent Emigration

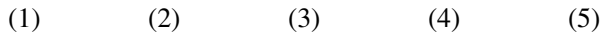

(6)

\begin{tabular}{lll}
\hline Droughts in last year & 0.0875 & 0.0690 \\
& $(0.0918)$ & $(0.0918)$
\end{tabular}

Droughts in last two years

$\begin{array}{ll}0.115 & 0.0998 \\ (0.0969) & (0.0959)\end{array}$

Droughts worse over last decade

\begin{tabular}{llllll} 
& & & & $0.220^{* *}$ & $0.199^{* *}$ \\
yes & yes & yes & yes & yes & yes \\
yes & yes & yes & yes & yes & yes \\
no & yes & no & yes & no & yes \\
1200 & 1200 & 1200 & 1200 & 1200 & 1200 \\
\hline
\end{tabular}

Included controls: average income, population, number of firms, students continuing to senior high school, students finishing secondary school

Standard errors in parentheses, ${ }^{*} \mathrm{p}<0.1 ;{ }^{* *} \mathrm{p}<0.05 ;{ }^{* * *} \mathrm{p}<0.01$ 


\section{Appendix: B Floods}

Table 15 Total Emigration and Flood (OLS regression results)

Dependent variable:

Log of Total Emigration
(1)
(2)
(3)
(4)
(5)
(6)

\begin{tabular}{|c|c|c|c|c|c|c|}
\hline \multicolumn{2}{|l|}{ Average income } & $\begin{array}{l}0.00000289 \\
(0.00000720)\end{array}$ & & $\begin{array}{l}0.00000234 \\
(0.00000720)\end{array}$ & & $\begin{array}{l}0.00000251 \\
(0.00000724)\end{array}$ \\
\hline \multirow{2}{*}{\multicolumn{2}{|c|}{ Population }} & -0.0000428 & & -0.0000427 & & -0.0000457 \\
\hline & & $(0.0000429)$ & & $(0.0000427)$ & & $(0.0000433)$ \\
\hline \multirow{2}{*}{\multicolumn{2}{|c|}{ Number of firms }} & $-0.00139^{* * *}$ & & $-0.00140^{* * *}$ & & $-0.00143^{* * *}$ \\
\hline & & $(0.000518)$ & & $(0.000521)$ & & $(0.000518)$ \\
\hline \multirow{2}{*}{$\begin{array}{l}\text { Students continuing to } \\
\text { senior high school }\end{array}$} & & -0.00291 & & -0.00295 & & -0.00297 \\
\hline & & $(0.00256)$ & & $(0.00256)$ & & $(0.00261)$ \\
\hline \multirow{2}{*}{$\begin{array}{l}\text { Students finishing sec- } \\
\text { ondary school }\end{array}$} & & 0.00500 & & 0.00494 & & 0.00489 \\
\hline & & $(0.00330)$ & & $(0.00327)$ & & $(0.00335)$ \\
\hline Floods in last year & $\begin{array}{l}0.0964 \\
(0.0958)\end{array}$ & $\begin{array}{l}0.105 \\
(0.0960)\end{array}$ & & & & \\
\hline Floods in last two years & & & $\begin{array}{l}0.143 \\
(0.0969)\end{array}$ & $\begin{array}{l}0.150 \\
(0.0971)\end{array}$ & & \\
\hline \multirow[t]{2}{*}{$\begin{array}{l}\text { Floods worse over last } \\
\text { decade }\end{array}$} & & & & & $0.255^{* *}$ & $0.271^{* * *}$ \\
\hline & & & & & $(0.102)$ & $(0.101)$ \\
\hline Commune-fixed-effects & yes & yes & yes & yes & yes & yes \\
\hline Time-fixed-effects & yes & yes & yes & yes & yes & yes \\
\hline Observations & 1200 & 1200 & 1200 & 1200 & 1200 & 1200 \\
\hline
\end{tabular}

Standard errors in parentheses, ${ }^{*} \mathrm{p}<0.1{ }^{* *} \mathrm{p}<0.05 ;{ }^{* * *} \mathrm{p}<0.01$

Table 16 Temporary Emigration and Flood (OLS regression results)

Dependent variable:

Log of Temporary Emigration

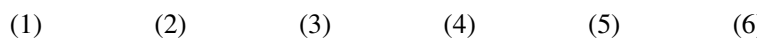

Floods in last year

$\begin{array}{ll}0.166 & 0.197 \\ (0.176) & (0.175)\end{array}$

Floods in last two years

$0.115 \quad 0.147$

(0.171) (0.170)

Floods worse over last decade

$0.332^{*} \quad 0.366^{*}$

Commune-fixed-effects

Time-fixed-effects

Other controls

Observations

$\begin{array}{ll}\text { yes } & \text { yes } \\ \text { yes } & \text { yes } \\ \text { no } & \text { yes } \\ 1200 & 1200\end{array}$

(0.195)

(0.194)

Observations

yes
yes
no
1200

yes

yes

yes

Included controls: average income, population, number of firms, students continuing to senior high school, students finishing secondary school

Standard errors in parentheses, ${ }^{*} \mathrm{p}<0.1 ;{ }^{* *} \mathrm{p}<0.05 ;{ }^{* * *} \mathrm{p}<0.01$ 
Table 17 Permanent Emigration and Flood (OLS regression results)

Dependent variable:

\section{Log of Permanent Emigration}
(1)
(2)
(3)
(4)
(5)
(6)

\begin{tabular}{lll}
\hline Floods in last year & $\begin{array}{l}0.0182 \\
(0.108)\end{array}$ & $\begin{array}{l}0.0208 \\
(0.109)\end{array}$
\end{tabular}

Floods in last two years

$\begin{array}{ll}0.148 & 0.146 \\ (0.107) & (0.108)\end{array}$

Floods worse over last decade

Commune-fixed-effects

Time-fixed-effects

yes

Other controls

Observations

no

1200

yes

yes

yes

$0.185^{*}$

$0.191^{*}$

(0.0976)

(0.0976)

Included controls: average income, population, number of firms, students continuing to senior high school, students finishing secondary school

Standard errors in parentheses, ${ }^{*} \mathrm{p}<0.1 ;{ }^{* *} \mathrm{p}<0.05 ;{ }^{* * *} \mathrm{p}<0.01$

\section{Appendix: C Typhoons}

Table 18 Total Emigration and Typhoons (OLS regression results)

Dependent variable:

Log of Total Emigration
(1)
(2)
(3)
(4)
(5)
(6)

\begin{tabular}{|c|c|c|c|c|c|c|}
\hline \multicolumn{2}{|l|}{ Average income } & $\begin{array}{l}0.00000336 \\
(0.00000719)\end{array}$ & & $\begin{array}{l}0.00000340 \\
(0.00000720)\end{array}$ & & $\begin{array}{l}0.00000343 \\
(0.00000719)\end{array}$ \\
\hline \multirow{2}{*}{\multicolumn{2}{|c|}{ Population }} & -0.0000446 & & -0.0000443 & & -0.0000445 \\
\hline & & $(0.0000429)$ & & $(0.0000428)$ & & $(0.0000429)$ \\
\hline \multirow{2}{*}{\multicolumn{2}{|c|}{ Number of firms }} & $-0.00137^{* * *}$ & & $-0.00137^{* * *}$ & & $-0.00136^{* * *}$ \\
\hline & & $(0.000509)$ & & $(0.000509)$ & & $(0.000510)$ \\
\hline \multirow{2}{*}{$\begin{array}{l}\text { Students continuing to } \\
\text { senior high school }\end{array}$} & & -0.00273 & & -0.00273 & & -0.00273 \\
\hline & & $(0.00255)$ & & $(0.00255)$ & & $(0.00255)$ \\
\hline \multirow{2}{*}{$\begin{array}{l}\text { Students finishing sec- } \\
\text { ondary school }\end{array}$} & & 0.00504 & & 0.00508 & & 0.00503 \\
\hline & & $(0.00335)$ & & $(0.00335)$ & & $(0.00333)$ \\
\hline Typhoons in last year & $\begin{array}{l}-0.0391 \\
(0.0952)\end{array}$ & $\begin{array}{l}-0.0330 \\
(0.0941)\end{array}$ & & & & \\
\hline Typhoons in last two years & & & $\begin{array}{l}-0.0570 \\
(0.0930)\end{array}$ & $\begin{array}{l}-0.0546 \\
(0.0915)\end{array}$ & & \\
\hline Typhoons worse over last decade & & & & & $\begin{array}{l}0.0777 \\
(0.0997)\end{array}$ & $\begin{array}{l}0.0676 \\
(0.0990)\end{array}$ \\
\hline Commune-fixed-effects & yes & yes & yes & yes & yes & yes \\
\hline Time-fixed-effects & yes & yes & yes & yes & yes & yes \\
\hline Observations & 1200 & 1200 & 1200 & 1200 & 1200 & 1200 \\
\hline
\end{tabular}

Standard errors in parentheses, ${ }^{*} \mathrm{p}<0.1 ;{ }^{* *} \mathrm{p}<0.05 ;{ }^{* * *} \mathrm{p}<0.01$ 
Table 19 Temporary Emigration and Typhoons (OLS regression results)

Dependent variable:

\section{Log of Temporary Emigration}
(1)
(2)
(3)
(4)
(5)
(6)

\begin{tabular}{|c|c|}
\hline Typhoons in last year & $\begin{array}{l}0.190 \\
(0.184)\end{array}$ \\
\hline
\end{tabular}

Typhoons in last two years

$0.183 \quad 0.187$

(0.185) (0.185)

Typhoons worse over last decade

\begin{tabular}{llllll} 
& & & & 0.0164 & -0.00396 \\
& & & & $(0.180)$ & $(0.181)$ \\
yes & yes & yes & yes & yes & yes \\
yes & yes & yes & yes & yes & yes \\
no & yes & no & yes & no & yes \\
1200 & 1200 & 1200 & 1200 & 1200 & 1200 \\
\hline
\end{tabular}

Included controls: average income, population, number of firms, students continuing to senior high school, students finishing secondary school

Standard errors in parentheses, ${ }^{*} \mathrm{p}<0.1 ;{ }^{* *} \mathrm{p}<0.05 ;{ }^{* * *} \mathrm{p}<0.01$

Table 20 Permanent Emigration and Typhoons (OLS regression results)

\section{Dependent variable:}

Log of Permanent Emigration
(1)
(2)
(3)

(4)

(5)

(6)

Typhoons in last year

$\begin{array}{ll}-0.0881 & -0.0851 \\ (0.0951) & (0.0949)\end{array}$

Typhoons in last two years

$\begin{array}{ll}-0.0558 & -0.0574 \\ (0.0922) & (0.0917)\end{array}$

Typhoons worse over last decade

\begin{tabular}{llllll} 
& & & & 0.0495 & 0.0448 \\
& & & & $(0.114)$ & $(0.114)$ \\
yes & yes & yes & yes & yes & yes \\
yes & yes & yes & yes & yes & yes \\
no & yes & no & yes & no & yes \\
1200 & 1200 & 1200 & 1200 & 1200 & 1200 \\
\hline
\end{tabular}

Commune-fixed-effects

Time-fixed-effects

Other controls

Observations

Included controls: average income, population, number of firms, students continuing to senior high school, students finishing secondary school

Standard errors in parentheses, ${ }^{*} \mathrm{p}<0.1 ;{ }^{* *} \mathrm{p}<0.05 ;{ }^{* * *} \mathrm{p}<0.01$ 


\section{References}

Allison PD (2009) Fixed effects regression models, vol 160. SAGE Publications, Thousand Oaks

Backhaus A, Martinez-Zarzoso I, Muris C (2015) Do climate variations explain bilateral migration? a gravity model analysis. IZA J Migr 4(3):4149

Beine M, Parsons C (2015) Climatic Factors as Determinants of International Migration. Scandinavian Journal of Economics 117:723-67

Beine M, Parsons C (2017) Climatic factors as determinants of international migration: Redux. CESifo Econ Stud 63(4):386-402

Bender MA, Knutson TR, Tuleya RE, Sirutis JJ, Vecchi GA, Garner ST, Held IM (2010) Modeled impact of anthropogenic warming on the frequency of intense atlantic hurricanes. Science 327:454-458

Berlemann M, Steinhardt M (2017) Climate change, natural disasters, and migration - a survey of the empirical evidence. CESifo Econ Stud 63(4):353-385

Bohra - Mishra P, Oppenheimer M, Hsiang SM (2014) Nonlinear permanent migration response to climatic variations but minimal response to disasters. In: Proceedings of the national academy of sciences United States of America, vol 111, pp 9780-5

Borjas G (1987) Self selection and the earnings of migrants. Am Econ Rev 77:531-553

Brandt K, Tarp F (2017) Characteristics of the VARHS data and other data sources. In: Growth, structural transformation, and rural change in Viet Nam, A rising dragon on the move. Oxford University Press, New York

Cattaneo C, Peri G (2016) The migration response to increasing temperatures. J Dev Econ 122:127-146

Christensen JH, Hewitson B, Busuioc A, Chen A, Gao X, Held I, Jones R, Kolli RK, Kwon W-T, Laprise R, Magaña Rueda V, Mearns L, Menendez CG, Räisänen J, Rinke A, Sarr A, Whett P (2007). In: Solomon S, Qin D, Manning M, Chen Z, Marquis M, Averyt KB, Tignor M, Miller HL (eds) Regional climate projections. Climate change 2007: The physical science basis,. Cambridge University Press, Cambridge

Coniglio ND, Pesce G (2015) Climate variability and international migration: An empirical analysis. Environ Dev Econ 20:1-35

Dai A (2011) Drought under global warming: A review. Wiley Interdiscip Rev Climate Change 2:45-65

Dallmann I, Millock K (2017) Climate variability and inter-state migration in India. CESifo Econ Stud 63(4):560-594

Dell M, Jones B, Olken B (2014) What do we learn from the weather? J Econ Lit 52(3):740-798

Di Falco S, Yesuf M, Kohlin G, Ringler C (2012) Estimating the impact of climate change on agriculture in low-income countries: Household level evidence from the nile basin, Ethiopia. Environ Resour Econ $52: 457-478$

Dun O (2011) Migration and displacement triggered by floods in the mekong delta. Int Migr 49:200-223

Duong LB, Linh TG, Thao NTP (2011) Social protection for rural-urban migrants in Vietnam: current situation, challenges and opportunities. CSP Research Report 08

General Statistics Office of Vietnam and United Nations Population Fund (2016) The 2015 national internal migration survey: Major findings, Hanoi, Vietnam

Global Facility for Disaster Reduction and Recovery (2011) Vulnerability, Risk reduction and adaptation to climate change: Vietnam. In: Climate risk and adaptation country profile. World Bank Group, Washington

Goldbach C (2017) Out - migration from Coastal Areas in Ghana and Indonesia - The role of Environmental Factors. CESifo Econ Stud 63:529-559

Gray C, Bilsborrow R (2013) Environmental influences on human migration in rural ecuador. Demography 50:1217-1241

Gray C, Mueller V (2012) Natural disasters and population mobility in Bangladesh. In: Proceedings of the national academy of sciences United States of America, vol 109, pp 6000-6005

Gröger A, Zylberberg Y (2016) Internal labor migration as a shock coping strategy: Evidence from a typhoon. Am Econ J Appl Econo 8:123-153

Gröschl J, Steinwachs T (2017) Do natural hazards cause international migration? CESifo Econ Stud 63:445480

Henry S, Schoumaker B, Beauchemin C (2004) The impact of rainfall on the first out-migration: A multilevel event history analysis in Burkina Faso. Popul Environ 25:423-460

Hirabayashi Y, Mahendran R, Koirala S, Konoshima L, Yamazaki D, Watanabe S, Kim H, Kanae S (2013) Global flood risk under climate change. Nat Clim Change 3:816-821

Huynh NT, Lin W, Ness LR, Occena - Gutierez D, Tran XD (2014) 12 climate change and its impact on cultural shifts in east and southeast Asia. In: A world after climate change and culture - shift. Springer, New York, pp 245-305 
Institute of Strategy and Policy on Natural Resources and Environment of Vietnam (2009) Vietnam assessment report on climate change, Hanoi, Vietnam

Ionesco D, Mokhnacheva D, Gemenne F (2017) The atlas of environmental migration. Routledge, London

Katzfey JJ, McGregor JL, Suppiah R (2014) High - resolution climate projections for Vietnam, Technical Report, CSIRO, Australia

Kharin VV, Zwiers FW, Zhang X, Hegerl GC (2007) Changes in temperature and precipitation extremes in the IPCC ensembles of global coupled model simulations. J Climate 20:1419-1444

Knutson TR, McBride JL, Chan J, Emanuel K, Holland G, Landsea C, Held I, Kossin JP, Srivasta AK, Sugi M (2010) Tropical cyclones and climate change. Nat Geosci 3:157-163

Koubi V, Stoll S, Spilker G (2016a) Perceptions of environmental change and migration decisions. Clim Change 138:439-451

Koubi V, Spilker G, Schaffer L, Bernauer T (2016b) Environmental stressors and migration: Evidence from Vietnam. World Dev 79:197-210

Lehmann J, Coumou D, Frieler K (2015) Increased record-breaking precipitation events under global warming. Clim Change 132(4):501-515

Liu Y, Stanturf J, Goodrick S (2009) Trends in global wildfire potential in a changing climate. For Ecol Manage 259:685-697

Millock K (2015) Migration and environment. Ann Rev Resour Econ 7:35-60

Ministry of Natural Resources and Environment of Vietnam (2016) Climate change and sea level rise scenarios for Vietnam, Hanoi, Vietnam

Nguyen QD, Renwick J, McGregor J (2014) Variations of surface temperature and rainfall in Vietnam from 1971 to 2010. Int J Clim 34:249-264

Paul BK (2005) Evidence Against Disaster-induced Migration: the 2004 Tornado in Bangladesh. Disasters 29:370-385

Pilarczyk KW, Nuoi NS (2005) Experience and practices on flood control in Vietnam. Water International $30(1)$

Reid H (2014) Climate change and human development. ZED Books, London

Revilla Diez J (2016) Vietnam 30 years after Doi Moi: Achievements and challenges. Zeitschrift für Wirtschaftsgeographie 60(3):121-133

Rosenzweig MR, Stark O (1989) Consumption smoothing, migration, and marriage: Evidence from rural India. J Polit Econ 97:905-926

Rummukainen M (2012) Changes in climate and weather extremes in the 21st century. Wiley Interdiscip Rev Climate Change 3:115-129

Ruyssen I, Rayp G (2014) Determinants of intraregional migration in sub - Saharan Africa 1980-2000. J Dev Stud 50:426-443

Schmidt - Thome P, Nguyen TH, Pham TL, Jarva J, Nuottimäki K (2015) Climate change in Vietnam. In: Climate change adaptation measures in Vietnam, SpringerBriefs in Earth Sciences, Springer

Thiede B, Gray C, Mueller V (2016) Climate variability and inter-provincial migration in South America, 1970-2011. Glob Environ Chang 41:228-240

Thomas V (2014) Confronting climate-related disasters in Asia and the Pacific. Rev Econ 65:121-136

Trung LD (2015) Economic and impacts of disasters in East Asia and policy responses: The case of Vietnamese communities, vol 18, Springer, Tokyo

$\mathrm{Vu}$ - Thanh H, Ngo - Duc T, Phan - Van T (2013) Evolution of meteorological drought characteristics in Vietnam during the 1961-2007 period. Theor Appl Climatol 118(3):367-375

Westra S, Fowler HJ, Evans JP, Alexander LV, Berg P, Johnson F, Kendon EJ, Lenderink G, Roberts NM (2014) Future changes to the intensity and frequency of short-duration extreme rainfall. Rev Geophys $52: 522-555$

World Bank (2010) Economics of adaptation to climate change - synthesis report. World Bank, Washington

Publisher's Note Springer Nature remains neutral with regard to jurisdictional claims in published maps and institutional affiliations. 